\title{
HUBUNGAN TINGKAT PENGETAHUAN DAN SIKAP TERHADAP PERILAKU MASYARAKAT DALAM MENGOLAH SAMPAH DI DUSUN PADUKUHAN DESA SIDOKARTO KECAMATAN GODEAN KABUPATEN SLEMAN YOGYAKARTA
}

\author{
Surahma Asti Mulasari \\ Fakultas Kesehatan Masyarakat Universitas Ahmad Dahlan Yogyakarta
}

\begin{abstract}
Background : People's habits in disposing waste by burning leaves or plastic waste has negative effect on health and also cause pollution. This is due to the lack of public knowledge in the processing of waste and the impact of the waste itself. This study aimed to determine the relationship between the level of knowledge and attitudes towards the behavior of the community in managing the daily garbage and waste management know that has been applied in the hamlet of Hamlet Village Sidokarto Godean Sleman district of Yogyakarta.
\end{abstract}

Method : The study was an observational analytic cross sectional design. Sampling technique used was random sampling. The data was collected using questionnaires, with a total sample of 77 households. Analysis of data was using univariate and bivariate analysis with statistical test Fisher's Exact Test.

Results : The statistical result of the study, showed that as many as six heads of families or at $(7.8 \%)$ had a level of knowledge that is not good in terms of waste management, and as many as 71 heads of households (respondent) or amount $(92.2 \%)$ had a level of knowledge both in terms of waste management, while 7 households (respondent) or equivalent $(9.1 \%)$ had a bad attitude in the process waste, and as many as 70 heads of households (respondent) or amount $(90.9 \%)$ had a good attitude in process waste. Bivariate analysis to the level of knowledge on the behavior of the Hamlet Hamlet Village Sidokarto Godean Sleman district of Yogyakarta in 2012 to process waste that is derived $p<0.05$ ( $p=$ $0.429)$ and $\mathrm{RP}=1.246$ (95\% Cl: 0.680 to 2.283$)$. While the bivariate analysis for the behavioral attitude towards Hamlet Hamlet Village Sidokarto Godean Sleman district of Yogyakarta in 2012 to process waste that is derived $p<0.05(p=0.088)$ and $R P=1.667(95 \% \mathrm{Cl}: 1.141$ to 2.434$)$.

Conclusion : There was no relationship between the level of knowledge of the behavior of people in the process waste in Hamlet Hamlet Village Sidokarto Godean Sleman district of Yogyakarta in 2012, and there is no relationship between attitude and behavior of people in the process waste in Hamlet Hamlet Village Sidokarto Godean Sleman district of Yogyakarta in 2012.

Keywords: knowledge, attitude, behaviour, trash

\section{PENDAHULUAN}

Tingginya laju pertumbuhan penduduk di beberapa bagian dunia ini menyebabkan jumlah penduduk meningkat begitu cepat. Mulai tahun 1650 laju pertumbuhan penduduk dunia semakin meningkat dengan cepat. Pada tahun 1650 jumlah penduduk di negara Eropa sebesar 113 juta jiwa, pada tahun 1750 menjadi 152,4 juta jiwa, dan kemudian pada tahun 1850 menjadi 325 juta jiwa. Jadi dalam dua abad jumlahnya menjadi tiga kali lipat, sedangkan untuk benua Asia-Afrika dalam jangka waktu yang sama jumlah penduduknya 
hanya berubah dua kali banyaknya ${ }^{1}$.

Sampah merupakan sesuatu bahan atau benda padat yang sudah tidak dipakai lagi oleh manusia, atau benda padat yang sudah tidak digunakan lagi dalam suatu kegiatan manusia dan dibuang ${ }^{2}$. Masyarakat banyak yang menganggap semua sampah itu kotor, menjijikan dan tidak berguna lagi sehingga harus dibuang atau membakarnya. Pemerintah sudah mulai kesulitan mencari tempat pembuangan akhir dari sampah karena banyak masyarakat yang tidak mau kalau wilayahnya dijadikan tempat pembuangan sampah. Hal ini dapat dipahami karena sampah yang menumpuk sangat mengganggu kenyamanan dan kesehatan, terutama dari bau dan keberadaan lalat ${ }^{3}$.

Pengetahuan adalah kesan dimana dalam pikiran manusia sebagai hasil dalam penggunaan panca indera, yang berbeda sekali dengan kepercayaan (belifes), takhayul (superstitious), maupun penerapan-penerapan yang keliru atau (misinformations) ${ }^{4}$. Sikap manusia didefinsikan dalam berbagai versi oleh para ahli. Berbagai definisi dan pengertian pada umumnya dapat memasukkan kedalam 3 (tiga) kerangka pemikiran yakni : kerangka pemikiran sikap adalah suatu bentuk evaluasi atau reaksi perasaan, sikap merupakan semacam kesiapan untuk bereaksi terhadap suatu objek denga cara-cara tertentu, dan berorientasi pada skema triadick (triadick scheme) ${ }^{5}$. Karena itu peneliti ingin mengetahui tentang hubungan antara tingkat pengetahuan dan sikap terhadap perilaku masyarakat dalam mengolah sampah di Dusun Padukuhan Desa Sidokarto Kecamatan Godean Kabupaten Sleman Yogyakarta Tahun 2012.

\section{Metode Penelitian}

Metode ini digunakan untuk mengetahui hubungan antara tingkat pengetahuan dan sikap terhadap perilaku masyarakat dalam mengolah sampah di Dusun Padukuhan Desa Sidokarto Kecamatan Godean Kabupaten Sleman Yogyakarta Tahun 2012.

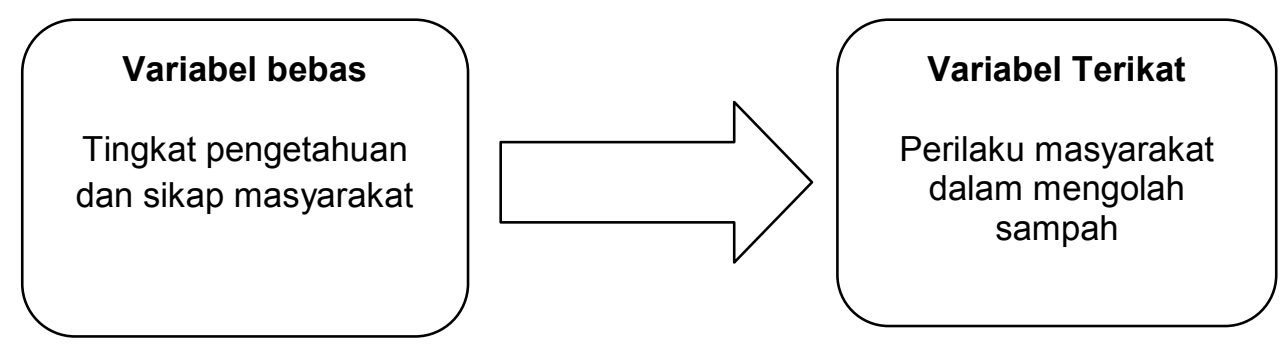

Gambar 1. Kerangka Konsep

KES MAS Vol. 6, No. 3, September 2012 : 144-211 
Populasi yang digunakan yaitu seluruh masyarakat Dusun Padukuhan Desa Sidokarto Kecamatan Godean Kabupaten Sleman Yogyakarta sebanyak 887 kepala keluarga. Sampel yang digunakan yaitu masyarakat Dusun Padukuhan Desa Sidokarto Kecamatan Godean Kabupaten Sleman Yogyakarta sebanyak 77 kepala keluarga (responden).

Analisis data yang digunakan adalah analisis univariat yaitu analisis yang digunakan untuk mendeskripsikan mengenai fernomena yang ditemukan di lapangaan atau ketika pengambilan data, dan analisis bivariat yaitu analisis yang dilakukan untuk menguji hipotesis antara dua variabel yang digunakan : tingkat pengetahuan dan sikap (variabel bebas), perilaku (variabel terikat), dan analisis statistik yang digunakan yaitu Fisher's Exact Test

\section{Hasil Penelitian dan Pembahasan}

\section{A. Hasil Penelitian}

a. Hasil Analisis Univariat

1. Distribusi Frekuensi Responden Menurut Tingkat Pengetahuan Masyarakat

Tabel 1. Tingkat Pengetahuan Masyarakat dalam Mengolah Sampah di Dusun Padukuhan Desa Sidokarto Kecamatan Godean Kabupaten Sleman Yogyakarta tahun 2012.

\begin{tabular}{llcccc}
\hline & & Frequency & Percent & $\begin{array}{c}\text { Valid } \\
\text { Percent }\end{array}$ & $\begin{array}{c}\text { Cumulative } \\
\text { Percent }\end{array}$ \\
\hline Valid & tidak baik & 6 & 7,8 & 7,8 & 7,8 \\
\hline & Baik & 71 & 92,2 & 92,2 & 100,0 \\
\hline Total & 77 & 100,0 & 100,0 & \\
\hline
\end{tabular}

2. Distribusi Frekuensi Responden Menurut Sikap Masyarakat

Tabel 2. Sikap Masyarakat dalam Mengolah Sampah di Dusun Padukuhan Desa Sidokarto Kecamatan Godean Kabupaten Sleman Yogyakarta tahun 2012.

\begin{tabular}{llcccc}
\hline & & Frequency & Percent & $\begin{array}{c}\text { Valid } \\
\text { Percent }\end{array}$ & $\begin{array}{c}\text { Cumulative } \\
\text { Percent }\end{array}$ \\
\hline Valid & tidak baik & 7 & 9,1 & 9,1 & 9,1 \\
\hline & Baik & 70 & 90,9 & 90,9 & 100,0 \\
\hline & Total & 77 & 100,0 & 100,0 & \\
\hline
\end{tabular}


3. Distribusi Frekuensi Responden Menurut Perilaku Masyarakat

Tabel 2. Perilaku Masyarakat dalam Mengolah Sampah di Dusun Padukuhan Desa Sidokarto Kecamatan Godean Kabupaten Sleman Yogyakarta tahun 2012.

\begin{tabular}{llcccc}
\hline & & Frequency & Percent & $\begin{array}{c}\text { Valid Per- } \\
\text { cent }\end{array}$ & $\begin{array}{c}\text { Cumulative } \\
\text { Percent }\end{array}$ \\
\hline Valid & tidak baik & 42 & 54,5 & 54,5 & 54,5 \\
\hline \multirow{2}{*}{ Baik } & 35 & 45,5 & 45,5 & 100,0 \\
\hline Total & 77 & 100,0 & 100,0 & \\
\hline
\end{tabular}

b. Hasil Analisis Bivariat

1. Hubungan tingkat pengetahuan dengan perilaku masyarakat dalam Mengolah Sampah di Dusun Padukuhan Desa Sidokarto Kecamatan Godean Kabupaten Sleman Yogyakarta tahun 2012.

\begin{tabular}{lcccccc}
\hline & \multicolumn{5}{c}{ Perilaku Mengolah } & \\
& & \multicolumn{2}{c}{ Sampah } & Total & $P$ & $R P$ \\
\cline { 2 - 6 } & $\begin{array}{c}\text { tidak } \\
\text { baik }\end{array}$ & baik & & & 1,246 \\
\hline T.Pengetahuan & $\begin{array}{c}\text { tidak } \\
\text { baik }\end{array}$ & 4 & 2 & 6 & & $\begin{array}{c}(95 \% \mathrm{Cl}: 0,680- \\
2,283)\end{array}$ \\
\hline botal & baik & 38 & 33 & 71 & 0,429 & \\
\hline
\end{tabular}

Hasil uji statistik dengan $\alpha=0,05$ didapatkan nilai $R P=1,246(95 \% \mathrm{Cl}:$ 0,6802,283 ) untuk tingkat pengetahuan, yang berarti bahwa tingkat pengetahuan yang kurang baik akan meningkatkan risiko terhadap tidak baiknya pengolahan sampah sebesar 1,246 kali lebih besar dibanding dengan tingkat pengetahuan yang baik, secara statistik tingkat pengetahuan tidak bermakna $(P=0,429)$.

2. Hubungan sikap dengan perilaku masyarakat dalam Mengolah Sampah di Dusun Padukuhan Desa Sidokarto Kecamatan Godean Kabupaten Sleman Yogyakarta tahun 2012.

\begin{tabular}{ccccccc}
\hline \multicolumn{5}{c}{ Serilaku Mengolah } & & \\
& & $\begin{array}{c}\text { tidak } \\
\text { baik }\end{array}$ & baik & & $P$ & $R P$ \\
\hline sikap & $\begin{array}{c}\text { tidak } \\
\text { baik }\end{array}$ & 6 & 1 & 7 & & 1,667 \\
\hline \multirow{2}{*}{ botal } & 36 & 34 & 70 & 0,088 & $\begin{array}{c}(95 \% \mathrm{Cl}: 1,141- \\
2,434)\end{array}$ \\
\hline
\end{tabular}

KES MAS Vol. 6, No. 3, September 2012 : 144-211 
Hasil uji statistik dengan $\alpha=0,05$ didapatkan nilai $R P=1,667$ (95\% Cl : 1,141-2,434), yang berarti bahwa sikap yang kurang baik akan meningkatkan risiko terhadap tidak baiknya pengolahan sampah sebesar 1,667 kali lebih besar dibandingkan dengan sikap yang baik dalam mengolah sampah. Secara statistik pada sikap tidak bermakna $(P=0,088)$.

\section{B. Pembahasan}

1. Tingkat pengetahuan masyarakat dalam mengolah sampah

Berdasarkan analisis dan hasil pengamatan dapat dilihat bahwa masyarakat Dusun Dukuh memiliki tingkat pengetahuan yang dominan masyarakatnya berpengetahuan baik. Hal ini ditunjukkan dengan jumlah responden yang sebagian besar $(92,2 \%)$ mempunyai tingkat pengetahuan yang baik dalam menjawab kuesioner yang diberikan. Responden yang memiliki tingkat pengetahuan tidak baik yaitu $7,8 \%$.

Penilaian terhadap tingkat pengetahuan responden didasarkan pada pemahaman kepala keluarga tentang sampah, sumber-sumber sampah, karakteristik sampah, faktor-faktor yang mempengaruhi jumlah produksi sampah, tahap pengelolaan sampah, pemanfaatan sampah secara umum adalah baik. Berdasarkan hasil pengamatan yang didapatkan menunjukkan bahwa tidak semua responden yang memilki tingkat pengetahuan baik memiliki sikap dan perilaku yang baik dalam melakukan pengelolaan sampah. Pengetahuan atau kognitif merupakan domain yang sangat penting untuk terbentuknya tindakan seseorang overt behavior. ${ }^{6}$

\section{Sikap masyarakat dalam mengolah sampah}

Berdasarkan analisis dan pengamatan yang dilakukan terhadap sikap masyarakat dapat dikatakan bahwa masyarakat Dusun Dukuh memiliki sikap yang baik dalam mengolah sampah. Hal ini ditunjukkan dengan data $(90,9 \%)$ masyarakat memiliki sikap yang baik dan sebanyak $(9,1 \%)$ masyarakat memiliki sikap yang tidak baik dalam mengolah sampah.

Sikap masyarakat yang kurang baik ini diperkirakan dipengaruhi oleh tingkat pengetahuan dan kematangan usia. Bagi sebagian responden yang menyatakan tidak setuju terhadap pengolahan sampah ini dipengaruhi oleh karena belum adanya sarana dan prasarana pengangkutan sampah di Dusun Dukuh sehingga sebagian besar masyarakatnya melakukan pembakaran sampah dan sebagian lainnya membuang sampah di tempat pembuangan sampah sekitar wilayah pasar sebagai upaya pengelolaan sampah dan kegiatan warga masyarakat yang melakukan pengelolaan sampah yaitu dengan memilah sampah-sampah seperti kaleng atau botol bekas untuk dijual kembali jumlahnya masih sangat sedikit.

Berdasarkan hasil tersebut, dapat diambil kesimpulan bahwa masyarakat di Dusun Dukuh belum memilki kegiatan pengolahan sampah yang baik karena sebagian masyarakat memilih melakukan pembakaran sampah yang sebetulnya kegiatan ini dapat menyebabkan gangguan kesehatan bagi masyarakat sendiri 
maupun merusak atau mencemari lingkungan dan membuang sampah di wilayah atau sekitar pasar, serta sejumlah pengelolaan sampah pun baru sebatas pemilahan atau pengumpulan jenis-jenis sampah tertentu yang bernilai ekonomis dan dapat dijual kembali.

\section{Perilaku masyarakat dalam mengolah sampah}

Berdasarkan analisis dan pengamatan yang dilakukan terhadap perilaku masyarakat dapat dikatakan bahwa sebagian masyarakat Dusun Dukuh memiliki perilaku yang tidak baik dalam mengolah sampah. Hal ini ditunjukkan sebanyak $(45,5 \%)$ masyarakat memiliki sikap yang baik dan sebanyak $(54,5 \%)$ masyarakat memiliki sikap yang tidak baik dalam mengolah sampah.

Hasil tersebut menunjukkan bahwa sebagian masyarakat Dusun Dukuh memiliki perilaku yang tidak baik dalam mengolah sampah, hal ini ditunjukkan dengan masih sedikitnya masyarakat yang mempunyai kesadaran mengolah sampahnya sendiri, dalam pengolahan sampah pun masih sebatas dalam kegiatan memilah sampah, yakni memisahkan antara sampah basah dan sampah kering, dan memanfaatkan lagi barang-barang yang masih layak pakai dengan menjualnya kembali. Tetapi, walaupun banyak masyarakat yang mengerti tentang cara pengolahan sampah namun keinginan atau pelaksanaan pengolahan sampah yang baik belum dilakukan sepenuhnya. Berdasar hasil observasi yang dilakukan bahwa di Dusun Dukuh terdapat tumpukantumpukan sampah yang dikumpulkan oleh setiap kepala keluarga dan kemudian sampah-sampah tersebut dibakar sehingga keadaan lingkungan sekitar tidak terlihat banyak sampah berserakan, dan sebagian masyarakat memilih membuang sampah yang mereka miliki di tempat penampungan sampah di wilayah sekitar pasar.

4. Hubungan antara tingkat pengetahuan dan sikap terhadap perilaku masyarakat dalam mengolah sampah di Dusun Padukuhan Desa Sidokarto

Diperoleh nilai $p=0,429$ dengan $\alpha=0,05$ yang berarti dapat dikatakan bahwa tidak ada hubungan antara tingkat pengetahuan dengan perilaku masyarakat dalam mengolah sampah di dusun Padukuhan desa Sidokarto kecamatan Godean kabupaten Sleman Yogyakarta tahun 2012. Nilai $R P=1,246(95 \% \mathrm{Cl}: 0,680-2,283)$ yang diperoleh menunjukkan bahwa masyarakat yang memiliki tingkat pengetahuan yang tidak baik akan meningkatkan risiko perilaku yang kurang baik terhadap pengolahan sampah sebesar 1,246 kali lebih besar dibandingkan dengan masyarakat yang mempunyai tingkat pengetahuan baik, dan dapat disimpulkan bahwa hasil ini tidak bermakna secara statistik dan biologis, sehingga dapat dikatakan bahwa tidak ada hubungan antara tingkat pengetahuan dengan perilaku masyarakat dalam mengolah sampah.

Diperoleh nilai $p=0,088$ dengan $\alpha=0,05$ yang berarti dapat dikatakan bahwa tidak ada hubungan antara sikap dengan perilaku masyarakat dalam mengolah sampah di dusun Padukuhan desa Sidokarto kecamatan Godean kabupaten Sleman Yogyakarta tahun 2012. Nilai $R P=1,667(95 \% \mathrm{Cl}: 1,141-2,434)$ yang diperoleh menunjukkan bahwa masyarakat yang memiliki sikap yang tidak baik akan meningkatkan risiko perilaku yang kurang baik terhadap pengolahan sampah sebesar 1,667 kali lebih besar 
dibandingkan dengan masyarakat yang mempunyai sikap yang baik, dan dapat disimpulkan bahwa hasil ini tidak bermakna secara statistik dan biologis.

Sikap masyarakat yang kurang baik ini diperkirakan dipengaruhi oleh tingkat pengetahuan dan kematangan usia. Bagi sebagian besar responden yang menyatakan tidak setuju terhadap pengolahan sampah ini dipengaruhi oleh karena belum adanya sarana dan prasarana pengangkutan sampah di Dusun Dukuh sehingga sebagian besar masyarakatnya melakukan pembakaran sampah dan sebagian lainnya membuang sampah di tempat pembuangan sampah di sekitar wilayah pasar, hal seperti itu menurut mereka sudah merupakan usaha pengolahan sampah akan tetapi pengolahan sampah yang seperti itu belumlah sepenuhnya benar, karena dari perilaku tersebut dapat mengakibatkan pencemaran lingkungan di tanah maupun udara akibat dari pembakaran sampah yang dilakukan.

\section{Simpulan dan Saran}

\section{A. Simpulan}

Tidak ada hubungan antara tingkat pengetahuan dan sikap terhadap perilaku masyarakat dalam mengolah sampah di Dusun Padukuhan Desa Sidokarto Kecamatan Godean Kabupaten Sleman Yogyakarta Tahun 2012. Dengan hasil uji statistik $\square=0,05$ didapatkan Nilai $R P=1,246(95 \% \mathrm{Cl}: 0,680-2,283)$ dan nilai $(p=0,426)$ untuk tingkat pengetahuan dan Nilai $R P=1,667(95 \% \mathrm{Cl}: 1,141-2,434)$ dan nilai $(p=0,088)$ untuk sikap.

\section{B. Saran}

\section{Pemerintah Desa}

Dapat lebih menggerakkan masyarakatnya untuk melakukan pengolahan sampah secara mandiri agar dapat tercipta masyarakat yang lebih baik lagi serta dapat menciptakan lingkungan yang lebih bersih dan meningkatkan derajat kesehatan di dusun Padukuhan pada khususnya.

\section{Kepala Dinas Kesehatan Kabupaten Sleman}

Perlu adanya penggalakan program dusun sehat dan terampil. Masyarakat perlu diarahkan untuk melakukan pengolahan sampah yang benar, dan diberikan pelatihan keterampilan untuk mengolah sampah menjadi kerajinan yang bernilai ekonomis serta peningkatan sarana dan prasarana untuk menjaga kebersihan dan melakukan intervensi mengenai pentingnya hidup sehat dan mandiri. 


\section{Daftar Pustaka}

1. Mantra, I. B., Demografi Umum, Pustaka Pelajar, Yogyakarta. 2010.

2. Notoatmodjo, S., IImu Kesehatan Masyarakat, PT. Rineka Cipta, Jakarta. 1997.

3. Notoatmodjo, S., IKM Prinsip-Prinsip Dasar, Rineka Cipta, Jakarta. 2003.

4. Soekanto, S., Sosiologi Suatu Pengantar, CV Rajawali, Jakarta. 2003.

5. Azwar, S., Sikap Manusia Teori dan Pengukurannya, Pustaka Pelajar, Jakarta. 2007.

6. Notoatmodjo, S., Kesehatan Masyarakat (IImu dan Seni), Rineka Cipta, Jakarta. 2007. 